\title{
Geographical Patterns and Geo-Economic Reasoning of the Pandemic Consequences: Old Geopolitical "Games" in the Post-COVID Global Order
}

\author{
Marta Zorko \\ University of Zagreb, Faculty of Political Science, Croatia \\ e-mail: marta.zorko@fpzg.hr
}

\author{
Josip Lučev \\ University of Zagreb, Faculty of Political Science, Croatia \\ e-mail: jlucev@gmail.com
}

\begin{abstract}
The research provides a two-type analysis of the consequences of the COVID-19 pandemic on the global world order after 2020. The first dimension of analysis is oriented towards geopolitical parameters, while the second is based on the geo-economic consequences of the pandemic crisis. The authors identified and classified three types of geopolitical games in the international community: the game of non-movement and labeling; the game of vaccine racing and the game of securitization. Furthermore, the goal is to identify potential consequences for the economy of certain countries, but also the postulates of international political economy due to the contemporary geographical, political and economic patterns of behavior in a global pandemic crisis. The main thesis is aimed at confirming predictable and common patterns of behavior that are accompanied by tested mechanisms of attempts to exercise power in the international community (classical geopolitical power games in the new conditions). The aim of this paper is to develop scenarios of potential changes in power relations at the global level and to analyse the consequences with regard to the outcomes of the three mentioned games. Scenario analysis is a common geopolitical qualitative method most commonly used to assess risk in different spheres of society. Large corporations are using it most often in calculating financial fluctuations in business processes and decision-making, but it also appears in a number of projections in industrial-technological processes and in American institutes. The methodology is similar in the cases of financial scenario analysis, while in other social sciences (primarily geopolitics and security studies) it is about discovering potential and alternative worlds. In geopolitics, it serves to project potential developments in the global environment with regard to the creation of new world orders, and phenomena that can change the predicted outcomes of reality. While analyses of new world orders can also be attributed to methods of prediction in international relations; in contrast, scenario analyses are more than forecasts of developments based on past trends. They primarily include considerations of unpredictable factors or reversals in international relations, where a global pandemic is certainly one of them.
\end{abstract}

Key words: geopolitics, geo-economics, pandemic, COVID-19, global world order. 


\section{Introduction}

The concept of Human Security has become the key security perspective in contemporary world. The linkage between personal security of an individual (or perceived personal security) and global security challenges seemed to be even more visible during the pandemic crisis in 2020. Nevertheless, such notion will be analysed and explained in a frame of three ongoing geopolitical games in international community identified and categorized by the authors. There is one working hypothesis connected to each game and the main goal is to discuss new paradigms of security, subjectivity and state role in the so-called New Global World Order we are potentially facing. The concept of New World Order arises in IR literature repeatedly after the major historical events that shattered the known balance of power in international community. Authors use such a concept trying to define new power relations in the current era after a concrete event that might influence global order (Freedman, 1991; Nye, 1992; Slaughter 1997). The term was often used to predict major changes in near future or great changes between major powers (Huntington, 1998). The term is also used by conspiracy theorists in the context of secret society ruling the World with the help of major international monetary organizations (Knock, 2019). Since the end of Cold War World Orders introduced by both "academics and practitioners have advanced a variety of concepts for a new 'world order'. These include a brief flirtation with a unipolar world/ American Empire (more recently, a Pax Sinica); a G2 'directorate' run by China and the United States; major power 'spheres of influence'; balance of power approaches; a multipolar arrangement of the world's larger powers; an ideological consortium of like-minded states (concert of democracies); and transnational networks led by non-state actors." (Steinberg, 2020: 551-552)

Regardless of former usage of the term, its controversies and forms, the New Normal concept introduced during the pandemic crisis call upon the revision and analysis of potential changes in international community as well as scenarios for power shifts that may be introduced by the New Global World Order in the New Normal circumstances. In the book "COVID-19 and World Order", edited by Hal Brands and Francis J. Gavin (2020) the term World Order is being commonly used. Due to the ambiguity of previous usage of the term New World Order (being introduced every five to ten years by pompous and world-as-we-know-it-ending thesis), and due to the fact that the authors in this paper consider changes in the very essence of existing world order, the term post-COVID global order will be introduced and used for the explanation of potential changes in world power relations. Those changes are oriented towards the shift in already ongoing geopolitical realms: new globalization nexus; new subjectivity and fragmentation of power - distribution among actors other than states (Zorko, 2018).

The key research questions are related to the analysis of new geopolitical games as a consequence of the pandemic crisis and pandemic related globalization of (in)security; new subjectivity emerged because of the pandemic; and state actions that resulted in the 
change of power due to the pandemic. As Brands and Gavin (2020:15) stated "while this disease, thankfully, is not likely to claim as many lives as the period from 1939 to 1945 did, its impacts on the global economy, on democracy, on public health, on food security, and on governance will reverberate for years to come." This paper focuses on impacts that this pandemic crisis might generate in global order and power relations taking into account abovementioned disruptions. Brands and Gavin (2020) are oriented towards the COVID-19 influence in issues of public health and climate change, international institutions and great power rivalry. However, this paper is oriented towards the visions of change in the global order, both between rivals and allies as well as in the system itself (with an emphasis on the concepts of territory, sovereignty, solidarity, autarchy, and global economy). The importance of critical geopolitical analysis of COVID-19 related consequences to world order lies in the fact that ongoing relations in international community tend towards competition, rather than cooperation. Competition in the form of identified geopolitical games will be proven to be more subtle than traditional geopolitical and geostrategic wars of the past, including new types of players and new values worth fighting for. Nevertheless, existing geographical patterns of political reasoning and acting are rooted in geopolitical culture and imaginations of involved subjects. As US journalist Tom McTague giving his future scenarios stated, "beyond the epidemiological challenges lies a slowly amassing threat that is not pathological in nature, but economic, political, and military. This is the geopolitical second wave, and its power is already starting to concern Western leaders". (The Atlantic, www.theatlantic.com, 9/24/2020). Indeed, right now, the geopolitical games of the pandemic crisis are making the World go round. Therefore, theoretical framework of critical geopolitical analysis, primarily in the areas of practical and popular geopolitics, will be used to demystify geographical patterns and power relations beyond COVID-19 geopolitical reasoning and games.

The first geopolitical game that influences future relations between states (and/or blocks of states) is related to the politics and policy of (non) movement. The first reaction to COVID-19 for the most states in the world was border closure. Such mechanisms of strong(er) border control or even completely closed borders have had its exceptions. Such imparities that will be further elaborated showed the paradox of the mechanism itself, as well as selective approach due to the nature of bilateral relations (moreover the perception of the quality of relations) between states. Another mechanism of COVID-19 related geopolitical game is red flagging. Red lists of COVID-19 influenced countries in day to day reports left mark on their international reputation, but even more important, left an imprint on their tourism attractiveness and potential business activity. No-go areas that are used as terminology of conflicts entered tourism perceptions of safe and unsafe places and areas. So-called COVID-19 passports makes this a two-way process - there will be admissible and non-admissible travelers depending on the status of vaccination. Bearing in mind shortages in some countries, long lists and priorities, on global, national and local levels, such development implies even 
deeper gaps between wealthy and poor nations and even privileged individuals. Finally, the third mechanism in the first geopolitical game of creating and writing spaces of insecurity and movement is labeling. China's virus, or Wuhan virus is the example how the theory of constructivism is applied in contemporary International Relations. Geographical victim blaming process on the global level influenced global power relations and daily re-territorialization of virus positive and virus negative space(s). The second strain of virus both in practical and popular geopolitical reasoning called Brazilian, South-African or U.K. strain confirmed this practice in public space.

The second geopolitical game is related to research, development and distribution of vaccine for COVID-19. As Asleigh Furlong (2020) quoted Suerie Moon (co-director of the Graduate Institute Geneva's Global Health Centre), countries that are on the breach of vaccine development do not have only "strategic assets, but power of military weapons; having access to a vaccine is a chance to strengthen a country's allegiances, political standing and prestige" (www.politico.eu, 7/29/2020). Indeed, shortly after the announcement of safe vaccine development the games of distribution began. The scenarios of potential vaccine development and distribution mirror current global power relations, influence and geographical presence, and may induce changes in regional/world order, especially in the area of economy. The competition between states in purchase, vaccine rollout, its benefits on state economy and tourism, (non)diversification of sources of supply, potential places of vaccine manufacturing leads towards the third geopolitical game - the game of securitization. Security issues with global outreach such as uncontrolled irregular migrations, pandemics, climate changes, environmental challenges, resource scarcity, are still being perceived as national security threats. They are being securitized trough national policies and politics leaving the space for international competition in the process of addressing those issues.

All three types of geopolitical games induced by pandemics have the power to change current world order, have the ability to influence bilateral (and multilateral) relations, have the possibility to construct new geographical reasoning both in IR and everyday life of individuals, and buster new kinds of subjectivity and further fragmentation of power in international community. Geo-economics and geopolitical analysis are used to describe three potential scenarios for post-COVID-19 World Order possibilities and parameters in its potential development. Scenario analysis is a qualitative method often used in geopolitics for the predictions of phenomena that could change realities and established relations. Therefore, instead of a conclusion, the main points of this paper are being explained trough potential scenarios for changes in global order, its causes and consequences. 


\section{COVID-19 related geopolitical games with economic consequences}

\subsection{First geopolitical game - new types of territorialization: The concept of space and movement in a pandemic environment}

The first geopolitical game is the one about space(s) and movement. In history, territory has been the most important tool for power games. Territorial expansion, resource wars, exploitation, and colonialism made great powers of the past rise and decline. Nowadays, territory poses as a pillar of sovereignty and a state asset. Power that could be gained trough territorial practices is oriented towards economic benefits (e.g. trade, transport or tourism). For such business perspective hard borders and border controls pose a serious issue and multiple potential economic loss. The abolition of the Schengen Agreement in Europe and closing borders all around the World, due to the pandemic crisis, challenged the usual chains of supply and interfered with established market relations. There is a documented "unprecedented shutdown of borders all around the world and restrictions on migration $(91 \%$ of the global population live in countries with restrictions on international arrivals, 39\% in countries with completely closed borders)" (Akkerman, 2020:1). Also, Lara-Valencia et. all (2020: 1) documented estimated reduction "of at least $80 \%$ in cross-border travel" of border experts "in their country of residence". A wall-building phenomenon along borders worldwide continues. Even more, COVID-19 comes handy in need of explanation of such practice in public sphere. Mark Akkerman (2020:1) finds that "amidst the pandemic, EU, US, Australia and others have continued to pour billions into fortifying borders, strengthening border patrol agencies (CBP, Frontex) and funding often authoritarian third countries to stop migration reaching their shores."

Lessons learned out of non-movement politics introduced in the pandemic crisis by border control policies may be defined as small changes with big consequences. It is not the first time that some of the border practices changed and border policies have gotten harder. But it is the first time that border closings have become the first recognized mechanism in fighting a disease globally. Global lockdown harvested tourist areas and made some services, for instance travel and fine dining, surplus. Andre Ishii noticed that both "locally-based industries have been devastated as well as globespanning industries, such as airline and tourism, which have been forecasted to suffer for years, with more layoffs to come" (www.geopoliticalmonitor.com, 6/2/2020). But each country has something to lose in this sector, so the question is, where does a geopolitical game take place in this example? Geographical patterns of (non) movement during the pandemic were (and still are) noticeable in selective border closing. Either in a sense of being selective towards neighboring countries (e.g. Croatia during the time of elections); being selective towards specific goods and services (e.g. export, import, transit); and being selective towards different groups of people (e.g. different protocol for different passports at those closed borders, not to mention migrant people in Europe). The paradox of closed borders and new bordering practice related 
to COVID-19 could be summarized in one question: how come if closed borders is a functioning mechanism and people are not travelling that the Virus still finds its way to travel? Or as a meme circulating on Internet has pointed out: 2020 - the year that the Virus travelled more than you did. As safe vaccine was developed, the question of travelling re-entered the global scene. "Immunity passports" or "risk-free certificates" (WHO, 2020a) are not yet approved by the World Health Organization which "paradoxically, signed an agreement with Estonia in October to collaborate on the development of a digital vaccination certificate - or a smart yellow card' (www.euronews.com, 2/3/2021). Nevertheless, countries such as Cyprus, Hungary, Iceland introduced free travel documents for vaccinated persons, with ten more EU member states announced to follow such practice (www.schengenvisainfo.com, 2/4/2021). Similar number of countries around the world are accepting vaccinated tourists without testing upon arrival and/or quarantine. There is even a consensus being reached on the EU level for introducing COVID-19 passports. This idea opens numerous questions due to the fact that only three types of vaccinations have been approved in the EU. Will COVID-19 passports with Sputnik V or China's vaccines be equal to Western ones? Is travelling in the future depending on the similarity of rules, but ideology as well? And, how will the new geographical patterns influence disobedient European countries and the not yet integrated parts of the European continent? Along with its controversies "vaccine passports are already becoming a mainstream idea. At the end of November, Australian carrier Qantas, for instance, became one of the first airlines to publically announce that they would only allow vaccinated passengers on board its flights in future" (www.euronews.com, 2/3/2021).

Space represents much more than just territory surrounded by borders. It consists of spatial practices related to territory, especially those of labeling and constructs. Hence geopolitical game related to territory is also the one of (non) selective red-flagging and labeling. Territorialization and re-territorialization of Virus positive and Virus negative Space is a circular process happening at political level and being accompanied and multiplied trough the mediatization and presentation of (un) safe spaces and vice-versa. The red lists of Virus infected countries change on daily basis influencing state economies, individual travel plans and an international (tourist) image of a particular country. Nevertheless, red-flagging does not depend solely on the numbers or statistics: it is a game of love and hate in IR as well.

And while red-flagging in Europe depends on particular interests and short-term coalitions of quid pro quo actions, globally it triggers the rise of competition among ideologically contested blocks in the seek for global domination. Benn Steil argues for the United States to consider the two worlds approach it took during the Cold War but this time against China (Steil, 2020). Such order "means limiting reliance on the authoritarian world while deepening American integration with other democracies." (Brands and Gavin, 2020: 36). Something Elisabeth Economy (2020: 739) calls 
"Cold War 2.0", is already visible in mutual victims blaming the process between USA and China. Bilateral labeling in media and political speeches implies a contest of who is more to blame for the current pandemic situation. The terms China's Virus or Wuhan Virus as well as China's assertive politics around the pandemic, show how the theory of constructivism functions in everyday political practice. Even more, Nail Ferguson (2020: 819) implies that Cold War II (as he calls it) is not a new phenomenon but merely an intensified one due to the COVID-19 pandemic, and at the same time a phenomenon that revealed "its existence to those who last year doubted it was happening."

Finally, geopolitics of (non)movement seeks for re-definition of globalization processes as we understand them. The notions of unequal globalization are not new ones. Czempiel (1999) stated twenty years ago that globalization is in its merit regional; The Lisbon Group in 1997 introduced the term of triadization as an uneven globalization happening primarily on the nexus between the Western world and tight relations between north America, west Europe and Japan (The Lisbon Group, 1997). Sassen in 2002 went even beyond theories of globalized national states in privileged geographical areas and introduced globalization activities and interconnections among world cities as carriers of globalization processes (Sassen, 2002). Nevertheless, that entire state-of-the-art only introduced the ongoing trends that the pandemic crisis proved happening in practice.

Newly discovered terms of de-globalization; over-globalization; and re-globalization need to be tested to avoid mistakes done in the past that led to the misuse of the term globalization in the 1990s (for more information how the term globalization was being a buzz word in the 1990s see: O Tuathail, 2000). There are several groups of authors noticing changes in the globalization processes, but are naming them differently. For instance, Andre Ishii (2020) states: "the current interruption of globalization could result in its irreversible shattering" (www.geopoliticalmonitor.com, 6/2/2020). Although he is not naming this interruption of globalization, he reminds us that this might not be the only example of such tectonic geopolitical changes in current history leaving up to interpretation what is his definition of globalization. After mentioning two World Wars and the Great Depression, he claims that they were events that "shattered British-led globalization" from the past (ibid.) He continues describing the following decades USA-led global view of the world, supported and regulated by the Bretton Woods System being reformed by neoliberal re-globalization initiated in the 1970s. (ibid.) For Ishii (2020) "the four-decades long inertia of neoliberal globalization" might be triggered by the COVID-19 crisis, slowing it down in the process of "firms redistributing production and supply-chains while also potentially driving states to onshore production of key strategic and critical products, thus emphasizing resiliency and security over cost-cutting" (www.geopoliticalmonitor.com, 6/2/2020). Although Ishii is being careful in his statements, he is clearly describing the process of 
De-globalization. And he is not being alone in this attempt. Brands and Gavin (2020: 36) warn us that on the long term the COVID-19 crisis is going to be remembered "as an economic crisis, not as an epidemiological one", since "it not only brought the global economy to a standstill — triggering the most rapid, if perhaps temporary, deglobalization the world has ever seen-but also revealed the weaknesses of existing international institutions for managing the global economy and the dangerous dependencies globalization had created." (Brands and Gavin, 2020: 36) The dangerous dependencies they argue about are seen in uneven globalization and unfair interconnections.

The phenomena arisen out of an unevenly globalized world in a constant change are threefold: "the interconnections of territory, the multiplication of actors, and the fragmentation of power" (Zorko, 2018:25-26). And while those processes have been visible for some time now, the COVID-19 crisis amplified them and showed their true faces. The interconnections of territory stand for uneven globalization and uneven links and interconnections, multiplication of actors refers to the rise of actors other than states in the international arena, and the fragmentation of power stands for the subsequent division of power between those new subjects. Geographical and geopolitical patterns of interconnections called globalization show a variety of imperfections and discontent in global world order. Brands and Gavin (2020: 48) noted that "complicating matters is the fact that COVID occurred amid a growing dissatisfaction with the effects of globalization and interdependence." Such dissatisfaction with Over-globalization existed previously to the pandemic crisis, but the crisis underlined the weaknesses and flaws of the world system. Some authors call the current type of globalization Hyper-globalization (Rodik, 2020). Brands and Gavin (2020: 50) noticed the fact "that globalization proved surprisingly fragile in the face of a raging pandemic - even countries within the European Union barred exports of critical goods and shut their borders... (but) ... The good news is that certain aspects of the system have worked fairly well. Similar to the 2007-9 global financial crisis, the US Federal Reserve acted as the banker to the world during the pandemic, providing much-needed liquidity to avoid a depression (albeit with less global coordination)."

Kori Schake (2020: 635) questions forms of a "more globalized world" by asking whether we reached "The End of Globalization". Schake recognized that the pandemic "has brought some elements of globalization to a screeching halt: movement of people across national boundaries has been completely stopped, shipping goods contracted to a tenth of their volume, and global supply chains have been revealed and questioned as countries limit export of medications, holding onto them instead for national consumption." (Schake, 2020: 653) Nevertheless, Schake confirms previous notions of world being Over-globalized turning now towards De-globalized but not only because of the pandemic crisis. The COVID-19 crisis only emphasized "trends left after 2008 global financial crisis in the area of cross-border investments, convert- 
ibility, geopolitical opportunities, cross-border data transmissions or research for artificial intelligence". (Schake, 2020: 655) Bearing in mind the effects of current state of globalization Brands et al (2020: 589) calls it "paradoxical" because "pandemics have happened in eras of far less globalization than our own. Yet the intensely interconnected nature of the modern world is one reason this disease went in just weeks from being a 'problem for China' to a global mega-crisis."

Re-globalization is therefore a call for rearrangement of dysfunctional or unjust interconnections in the global order, which may boost security challenges in contemporary world. Brands et al (2020) finds an opportunity in this turning point as it could "create opportunities to pursue a smarter, more geopolitically savvy globalization, to reinvest in partnerships with liberal democracies, and to forge a stronger counterbalancing coalition against a neo-totalitarian China." (Brands and Gavin, 2020: 39) Or, as Schake (2020: 674) suggests "the experience of the pandemic should occasion reconsideration of what Nick Eberstadt terms "global integration without solidarity." Re-globalization on regional principles overcomes a territorial gap in globalization processes caused by the politics of non-movement due to different crises. Re-emerging globalization, as Steinberg (2020: 599) reminds us "will increasingly occur within rather than across geopolitical lines", and therefore bottom-up regional globalization due to the geographic proximity is more likely to occur in the post-COVID era.

\subsection{Second geopolitical game - new subjects and new types of subjectivity: The geopolitics of vaccine and The New Global Order? New positions in old Power Games}

This geopolitical game could be summarized around the terms of vaccine nationalism and power gaining issues, the coalitions of help providers not by need but by alliances, strategic humane actions and selective aid provision. The term vaccine nationalism was used in the State of the Union speech addressing potential games related to research, development and distribution of COVID-19 vaccine. Ursula von der Leyen stated several times that "the vaccine must be deployed at an affordable price to "every single corner of the world'." (www.politico.eu, 7/29/2020). Such notions were now confirmed in her speech: "none of us will be safe until all of us are safe - wherever we live, whatever we have. An accessible, affordable and safe vaccine is the world's most promising way to do that. At the beginning of the pandemic, there was no funding, no global framework for a COVID vaccine - just the rush to be the first to get one. This is the moment the EU stepped up to lead the global response." (State of the Union..., 2020) No matter the mechanisms of collaboration being established, some countries are still insisting on individual attempts.

The situation around $\mathrm{R} \& \mathrm{D}$ attempts and vaccine could be easily divided into three categories. First one is a WHO and EU-led coalition of more than 40 counties gath- 
ered around the COVAX global facility attempting to find and distribute vaccine evenly. Only EU "contributed 400 million euro to help ensure that safe vaccines are available not only for those who can afford it - but for everyone who needs it. (because) Vaccine nationalism puts lives at risk. Vaccine cooperation saves them." (State of the Union..., 2020) Nevertheless, the participation in COVAX is voluntary and some of the countries included in the project are continuing bilateral agreements for COVID-19 vaccine in parallel arrangements. Furlong (2020) noticed, "trade-off isn't lost on wealthy nations, which are beginning to express interest in COVAX. However, some countries have continued to agree bilateral deals, leading to concern that countries could be negotiating twice for the same vaccines. How exactly a vaccine would be distributed if a government has both a bilateral deal with a manufacturer and is part of COVAX is unclear". (www.politico.eu, 7/29/2020) Not to mention that in the COVAX system it is left unclear on which principles the distribution is going to be done once the vaccine reaches national level of distribution. The questions whether vaccine should be reserved for medical care workers and/or the elderly, whether it should be distributed to general population on voluntary basis, or how is any type of distribution going to reflect poor people, minorities, migrants of people without medical care still remains unanswered. So, even the plan invoking the global solidarity principle has its flaws and has to be further considered. But as Brands and Gavin (2020: 54) stated, the pandemic crisis has shown advantages of cooperation "and revealed underlying strengths of the current world order. For example, the unprecedented sharing of scientific information and the drive for therapies and a vaccine remind us of the breathtaking economic, intellectual, and scientific advances that have occurred in recent decades".

The second group could be called "vaccine nationalism" (State of the Union..., 2020) and consists of individual R\&D attempts by major powers, finding the vaccine as an opportunity to strengthen its position in the current global order. USA, China, Russia and even UK strive above the care for human health - it is becoming a tool for possible gaining of world power and leadership position. Parallel to R\&D those countries are conducting bilateral negotiations with major pharmaceutical companies developing the vaccine and insisting on primacy for distribution. Some authors also define this process as a form of cooperation. Inglesby (2020: 175) noticed, "with an extraordinary number of COVID-19 vaccine projects under way, this is the biggest and fastest vaccine development project in history. The major lines of effort are being funded by the United States, China, and an international collaboration run by the Coalition for Epidemic Preparedness Innovations in a partnership with WHO-all working in partnership with biotech or leading global vaccine companies." No matter if called a partnership, a cooperation on the biggest project in history, or geopolitical games around vaccine development, this category is about vaccine serving multiple purposes other than human health. Thinking about vaccine trough economic or geopolitical lenses allows it to become a tool, or even a weapon. Vaccine "is not purely 
about protecting a population's health. As many experts see it, a vaccine is also vital in getting economies back on track." (www.politico.eu, 7/29/2020) And the very moment vaccine is being perceived as a tool for economy recovery, each player starts to play its own geopolitical game.

The third category consists of countries that are on the margins of the current global geopolitical order (e.g. Cuba); non-state actors (e.g. multinational companies or even individuals); and terrorist groups. And while the latter have no capabilities in R\&D sector for vaccine development and production, they might potentially influence its distribution. Non-state actors, namely multinational pharmaceutical and medical supply companies, will hugely benefit out of their prior bilateral or even multilateral agreements. Cuba serves as an example for individual player in this area. The notion of SOBERANA-1 anti-COVID-19 vaccine being developed in Cuba put this country among 30 world leaders in R\&D and made it the only country in Latin America with such a possibility. Although not quietly recognized as an equal player among leading nations, Cuban program is being grounded in the long tradition of investment in medical education in Cuba, and "despite the economic blockade and limited resources, Cuba maintains its education and health systems free and is conducting clinical trials of its own vaccine against COVID-19, SOBERANA-01" (Haro Sly, 2020, www.americalatina.net. br, 9/28/2020). Eventually, SOBERANA-2 was also developed and reached phase 2 of testing by December 2020 (Zimmer, Corum and Wee, 2021). Interestingly, SOBERANA means SOVEREIGN and implicates the intentions for positioning in the ongoing global vaccine game. Other countries on the margins of the global order do not have capacities to engage in global competition, but wild cards are always possible.

There are 73 vaccine candidates that have started clinical trials as of late February 2021 (WHO, 2021), a substantial and rapid increase from 36 in late September 2020 (WHO, 2020b). These trials are usually conducted in three phases ${ }^{1}$ of increasing cost and complexity before being approved for use. The urgency of the COVID-19 pandemic brought about this vast number of simultaneous attempts to produce a vaccine, whereby the best global scientific centers are essentially competing to produce a solution. Table 1 summarizes the most advanced vaccines. The first column shows the vaccines that have reached Phase 3 trials, while the second column shows those that have also reached limited approval (although not yet completing Phase 3 ).

According to Zimmer, Corum and Wee (2021), the most widely quickly developed and accepted vaccines as of 26 February 2021 are:

${ }^{1}$ In practice, greater variety is possible with an optional exploratory Phase 0 , a post market Phase 4, subphases $a$ and b (e.g. Phase 1a) or combined phases (e.g. Phase 2/3). 
- Comirnaty, developed by Pfizer and BioNTech (USA/Germany) which is fully approved in 5 states (Bahrain, Brazil, New Zealand, Saudi Arabia, Switzerland) and approved for emergency use in 31 entities, counting EU as a single entity (ibid), which suggests some form of approval in 62 states altogether.

- AZD1222/Covishield, developed by the University of Oxford and AstraZeneca (UK/Sweden) is approved for emergency use in 32 entities, counting EU as a single entity (ibid) and suggesting some form of approval in 58 states altogether.

- Sputnik V, developed by Gamaleya Research Institute (at the Russian Ministry of Health), which is approved for use in Russia and approved for emergency use in 36 entities (ibid), which is 37 entities altogether.

- mRNA-1273, developed by Moderna (USA), later in partership with National Institutes of Health (USA), which is fully approved in Switzerland and approved for emergency use in 10 entities, again counting EU as a single entity (ibid) and suggesting some form of approval in 37 states altogether.

- BBIBP-CorV, developed by Sinopharm (China) is fully approved in Bahrain, UAE and China, and approved for emergency or limited use in 12 other countries (ibid), suggesting some form of approval in 15 states altogether.

- CoronaVac, developed by Sinovac (China) is fully approved in China and approved for emergency use in 12 other states (ibid) suggesting some form of approval in 13 states altogether.

Geopolitical faultlines clearly play a role in vaccine approvals, and approvals of Sputnik $\mathrm{V}$ seem to be indicative of this. The only $\mathrm{EU}$ member to approve this vaccine as of 26 February 2021 is Hungary (which is incidentally also the only EU member to approve one of the vaccines developed in China). Apart from Hungary, the only other NATO member to approve Sputnik V is Montenegro. It was approved by Republika Srpska, but not the rest of Bosnia and Herzegovina, and it seems to be the only vaccine approved for use in Iran (although Iran is developing its own vaccines and has partnered with Cuba for phase 3 testing of Soberana-2) and Venezuela (ibid).

Some commenters have framed this competition in terms of specific varieties of capitalism and their effects on innovation. Market-oriented economies (like USA, UK or Australia) are more prone to radical innovation, while more strategically oriented economies (like Germany, Sweden or Japan) are more likely to produce steady and incremental innovations $s^{2}$. As vaccines and cures are "more likely to represent radical innovation, its origin will supposedly be naturally found in one of the market-oriented developed economies" (The Economist, 9/12/2020:66). However, varieties of capitalist

2 This dichotomy between two major varieties of capitalism is usually rendered as Liberal Market Economies (LMEs) and Coordinated Market Economies (CMEs) and has been an influential strand of literature since Hall and Soskice (2001). The types of innovation are embedded in broader incentive structures provided by complementary institutions. For more, see Lučev and Babić (2013). 
attempt to describe business as usual, while the present situation is better described as an urgent scramble for a desperately needed result. Funds and other resources that might not otherwise be available are now focused on the vaccine. The first effective and safe vaccines may have the benefit in obvious and economic terms (profiting from extremely high demand), but also in terms of political benefits for the country of origin.

\subsection{Third geopolitical game - new distribution and fragmentation of power: The game of Securitization}

Distribution of power in crisis situations does not only affect interstate relations and change in global order, but power-shifts on micro-regional levels generate chances and challenges for global players as well. Securitization in times of the pandemic is visible in non-security sectors, as well as in security sector on nation-state level; it is being confirmed and multiplied trough politics and media; and as a consequence invokes global competition.

As Steinberg (2020:547) noticed "the twin, interrelated crises of COVID-19 and the breakdown of economic globalization have demonstrated both the weakness of current 'world order' (or perhaps the lack of world order) and the urgent need for some kind of framework to manage these and future challenges going forward." But, the framework that is currently being used worldwide, no matter the challenge in question, is the one of securitization. Securitization of an issue has wide benefits for political elites: it gives them tools and mechanisms for action; it strengthens their position on national level; and, if successful in playing the war game, gives the recognition or even better position on international level. On the other hand, securitization may lead to the hardening of a political view and orientation, radicalization, militarization and undermining of a humane perspective or even human rights. Righteous warriors leading the war against the Virus gain individual political points both on national level - bolstering the position for next elections - as well as on international level in being recognized as successful world leaders. Ishii (2020) noticed "traditionalist expression of religions have returned ... the post-COVID-19 world may face long-term consequences that not only affect immediate geopolitical configurations and alter domestic balances of power and even fundamental worldviews. This may be an especially pressing element for states where more binary-entrenching extreme political views have taken deeper root (including those in the West)". Akkerman (2020: 1) also recognized "racist media outlets, organizations, far-right parties and governments (US, Israel, Brazil, Iran, Hungary) have used the crisis to stoke xenophobic sentiments". Even before the pandemic crisis there have been notions of coexistence in "a multipolar world whose aims and values no longer necessarily align with those of liberal democracy. At this moment, $54 \%$ of the world's population now lives under some form of authoritarian rule. The COVID-19 pandemic has only accelerated these trend lines." (Brands and Gavin, 2020:13-14) 
One of the consequences of securitization is over-militarization. The already mentioned border fortifying processes around the globe are being accompanied by military engagement. Akkerman (2020: 1) finds "border militarization has intensified using the excuse of COVID-19, leading to increased troops and hardware deployed on many borders worldwide (US, Peru, Ecuador, Colombia, Brazil, Greece, Poland, the Czech Republic, Latvia, Lithuania, the Netherlands, North Macedonia, Portugal, Slovakia and Slovenia)". Political elites are not the only winners in this securitization game. Multinational companies, corporations, IT and biometric firms "continued to receive record levels of border control contracts ... many of the companies winning contracts for surveilling, monitoring and tracking migrants have also pitched their same technologies for health and policing related to COVID-19. They will be one of the few winners of the COVID-19 fuelled border militarization bonanza." (Akkerman, 2020: 1) Brands and Gavin (2020: 44) anticipate potential change in this trend only after soft security threats will be perceived as more important than hard security ones, or in case "COVID ends up killing, just within the United States, a number of people that is orders of magnitude higher than the number that died on $9 / 11$ ". Unfortunately their claim that "the military balance of power is becoming passé" (2020: 45) is neither being followed by practical examples nor will it be until soft security challenges are de-securitized.

This imbalance between types of security threats belonging to soft security and hard security mechanisms that follow them tackle the above-mentioned thesis on contemporary subjectivity in IR, geopolitics and security studies. Overlapping spectrum of global threats, national security mechanisms, and human security protection leaves space for unpreparedness in planning, uncertainty of measures, and possibility of violating human rights. There is no either/or approach to contemporary challenges - a vicious circle of securitization on behalf of politics and to the cost of security needs to be broken. Brands and Gavin (2020: 45) see an enlightening opportunity that "the real takeaway from COVID may be that hard and soft threats often work in tandem, potentially mixing and combining in powerful ways. Geopolitical rivalry may make transnational threats harder to combat; transnational threats can sharpen geopolitical rivalries and instability." Therefore, only thinking outside the box of national security paradigms could address global threats and secure individuals.

\section{Towards New Global Order: Self-sufficiency, Autarchy and the Ensuring State Concept vs. Global Solidarity Concept}

Warnings from scholars are that the COVID-19 crisis started and will end as a food security crisis. Jessica Fanzo (2020: 309) reminds "COVID-19 Began as a Food System Risk". Due to local eating habits a zoonosis ended in a pandemic and therefore showed fragility in the current food security system. Lockdown and closed borders worldwide during the pandemic crisis highlighted the importance of national selfsufficiency related to food. And while medical supplies were a matter of international bargaining and aid, food became the core of the ensuring state concept. This is the 
concept introduced by Anthony Giddens (2009) explaining how state should be the first and ensuring component in the fight against climate changes. The pandemic crisis showed similar tendencies - states turning towards own production, local supply chains proved to be the only functional ones and the state financially encouraged a switch in industries that were made surplus over night. And, "while stocks are adequate, the downstream effects along the food supply chain are showing vulnerabilities and disruptions; some are calling to move away from long globalized food supply chains to short local supply chains.” (Fanzo, 2020: 313)

The question that remains is whether such trend will leave its impact in the postCOVID time and if states would seek for comforting solutions in autarchy and selfsufficiency. Jill Hobbs (2020:1) considers whether "the COVID-19 pandemic will have longer-lasting effects on the nature of food supply chains, including the growth of the online grocery delivery sector, and the extent to which consumers will prioritize 'local' food supply chains" finding it very likely to happen as a bottom-up process of demand. Theses against the ensuring state concept are those recognizing the fact states are unable to provide solely the solutions in the areas of "technology, climate, and food. In each of these areas, purely national solutions to accelerating challenges are unworkable. And in each of these areas, COVID-19 has highlighted the urgency of action." (Brands and Gavin, 2020: 35) Jessica Fanzo (2020: 326) recognizes the necessity of "World Order for Food Security" since "none of technical recommendations to fix food systems is sustainable in the current fractured and sclerotic global politically enabling environment". She argues, "for food systems to function effectively, equitably, and sufficiently during the pandemic and long after, the political environment must embrace global cooperation and inclusion, support private sector engagement, and minimize political polarization and geopolitical competition.” (Fanzo, 2020: 326) Such call for a global solidarity concept has human security approach in its merits. Food and water are both being strategic resources as well as human life necessities. Food and water scarcity should not serve as a tool for geopolitical games since insecurities related to those resources generate insecurities on global level, even wars. At the same time being an essence for human lives, both food and water may serve as a powerful weapon. Fanzo (2020: 307) argues, "food security is highly correlated with international security. Lasting food insecurity has been shown to lead to social unrest, food riots, radicalization, instability, and conflict." Moreover, already existing food related instabilities were triggered by the pandemic crisis and lead towards "a potential hunger pandemic" (www.geopoliticalmonitor.com, 6/2/2020). Ishii (2020) reminds us of numbers and consequences: "the United Nations World Food Programme (WFP) has warned in April of a nutritional crisis that may engulf regions of the world resulting in up to 265 million people experiencing starvation by the end of $2020 \ldots$ inflation in food prices has been determined as a factor in instigating 'Arab Spring' revolts that toppled MENA governments early in the last decade, geopolitical ripples resulting from a potential hunger pandemic should not be ignored" (ibid.). 


\section{Economy trends of geopolitical games and New Normal Global Order}

Intellectual tradition and policy prescriptions concerning international trade have had a tumultuous past. Protectionism in one form or another was present at the forefront in various periods. In terms of intellectual tradition it would include mercantilist thought, Alexander Hamilton, Friedrich Liszt, John Maynard Keynes, import substitution development and structuralism to the tune of Prebisch-Singer and world systems analysis. Trade liberalism was, however, more successful both in terms of theoretical and practical domination. Its tradition stems at least from Adam Smith, and continues via David Ricardo, Heckscher-Ohlin theorem, to be made subtler through the New trade theory of the late 1970s. It is safe to say that amongst policy experts free-market ideas are currently prevalent. In 2012, a panel of 41 top economic experts was surveyed on the influence of free trade and unsurprisingly, $85 \%$ either agreed or strongly agreed on overwhelming free trade benefits, and none disagreed (IGM Economic Experts Panel, 2012).

In terms of practice, free trade has made gradual gains in the West since World War 2. Restraints on free trade (customs and quotas) and other obstructions of international economic flows have been gradually lifted through GATT, IMF and WTO. The process expanded and intensified in the 1990s. Firstly, the fall of the Iron Curtain heralded the expansion of global supply chains through the inclusion of Central and Eastern European socialist economies into the global economic system. China was also opening in order to be included on its own terms. This expanding process left out only few stragglers like North Korea, which still strived for the communist ideal of autarchy. Secondly, international economic integration became increasingly more regional in nature. Since the early 1990s, there was a remarkable proliferation of FTA (Free Trade Area), customs unions and similar arrangements (WTO, 2020), which provided smaller numbers of trading partners with a more deeply, integrated economic playing field. Some critics have pointed out that such regional integrations obstruct the true liberal goal of global free trade and that the complex relationships between various partners make the world resemble a "spaghetti bowl“ (Bhagwati, 2003: 112).

We would do well to note the old hegemonic stability theory in the context of International Political Economy. This theory saw international economic openness as a result of an existence of a single dominant power (Ravenhill, 2011:23). The "first" globalization of the late 19th and early 20th century is then seen as a result of British domination, while the „second" globalization in the second half of the 20th century is understood to be the effect of the US domination. Through these lenses, we can note that the various regional economic integrations are an alternative to the US-led post-war Bretton Woods project, in which the economy of the West hinged on the economy of USA. In this sense, regional integrations (led by the imperfect example of 
the European Union) are a result of the waning of US competitiveness and a lack of its interest to further the global free trade agenda. However, the levels already reached by the mid 1990s and the establishment of WTO provided an already free playing field for international trade, which grew even more liberal within various regional integrations.

All of this provides us with a view of globalization of the past decades as a complex phenomenon in which free-trade ideas are intertwined with an increasingly multipolar world. The economic reality was a continued liberalization at the intersection of two tendencies (global and regional) and the result was the ever-developing global supply chain. Economic processes ended up in a mesh of geography and economy due to the availability of production locations and markets across the world. Companies founded since the early 1990s could easily be "born global", or founded expressly with the goal of functioning in the globalizing economy, rather than in the confines of a single national economy (Dicken, 2007; Ietto-Gillies, 2005). However, this also contributed to the vulnerability of the entire world to events in a specific location. Such a world - globalized, liberal, mutually embedded and market-oriented as it was - met with three types of shocks in recent years. All of these worked to subvert some of its crucial elements. Firstly, the global financial crisis and recession of 2008/09 provided a reminder of the inherent vulnerability and caused some countries to pursue alternative growth models. Most notably, China reoriented from a heavily export-driven path to an increasingly domestic consumption oriented one (for more see Lučev, 2021: 247253). This is a form of structural decoupling in which economic ties and possibilities may remain the same as they were, but the importance of international trade to the overall national economy diminishes. Secondly, in the years following the first shock, protectionist-minded narratives developed and were politically-operationalized. The most notable European result was Brexit, through which UK decided to partially decouple from European integrations. In USA, Donald Trump ran an „America first“ campaign and his administration was true to it in that it pursued trade wars since 2016 (see Liu and Woo, 2018). Thirdly, the COVID-19 crisis that has begun developing since early 2020 has seen another kind of decoupling. The health risks, lockdowns and restrictions to international travel have produced a significant drop in global trade, GDP and tourism and has also created incentives to reassure some of the production that has been offshored to more competitive locations.

To assess the effects of such economic decoupling we must first take stock of the specific structural positions that specific national economies find themselves in. Table 1 shows the sizes of imports, exports and net trade relative to the size (\% GDP) of selected economies. 
Table 1.

Trade positions in selected economies (data for 2019 or most recent)

\begin{tabular}{|l|c|c|c|}
\hline & Import (\%GDP) & Export (\%GDP) & Net trade (\%GDP) \\
\hline USA & 14.58 & 11.73 & -2.85 \\
\hline Germany & 41.10 & 46.89 & +5.79 \\
\hline PR China & $18.23(2018)$ & $19.04(2018)$ & +0.81 \\
\hline Canada & 34.04 & 31.64 & -2.4 \\
\hline France & 32.75 & 31.77 & -0.98 \\
\hline UK & 32.68 & 31.60 & -1.08 \\
\hline Japan & $18.29(2018)$ & $18.52(2018)$ & +0.23 \\
\hline Russia & 20.76 & 28.31 & +7.55 \\
\hline
\end{tabular}

Source: OECD, 2020; own calculation

We can observe that these countries have very different structural effects of international trade for their economy. Firstly, the exposure to the international economy via trade is diverse with trade (exports + imports) representing as much as 88\% GDP in Germany $^{3}$, and as little as $26.3 \%$ in USA. As we have already noted, the structural importance of trade in China has underwent a substantial decline in recent years. In 2006 its combined exports and imports were equal to 64.4\% GDP, while in 2018 they were equal to only $37.3 \%$ (OECD, 2020), which is a testament to the radical reorientation of the growth model ${ }^{4}$. Secondly the countries in Table 1 diverge on the macroeconomic effects of trade as well. The net trade as a percentage of GDP reflects the structural importance of trade deficits or trade surpluses. The US trade deficit equivalent to $2.6 \%$ GDP by definition means that the US economy is $2.6 \%$ smaller than it would have been in the case of a balanced trade position. The deficits were substantially larger before the last crisis (5.5\% GDP in 2006), but they remain irritating and provide some motivation for an attempt to reduce them. However, free trade provides various static and dynamic benefits including overall larger economies, greater efficiency and lower prices and global supply chains have grown so complex that an increase in trade restrictions may be tantamount to a shock to the markets. These are some of the reasons why the economic mainstream is in favor of free trade, as we have noted. Nevertheless, it is clear to see that countries with large trade deficits would be more likely to develop protectionist narratives and policies, as the shortterm political motivations develop in a different atmosphere compared to countries that run trade surpluses. One such country is Germany, whose position within the EU helps it to form substantial and continued trade surpluses (5.8\% GDP in 2019). This

3 This is by no means a record, as smaller economies are often more dependent on international trade which represents $381.6 \%$ of GDP in Luxemburg, 239.2\% in Ireland and 185.2\% Slovakia (OECD, 2020)

${ }^{4}$ In the same period, this figure rose by 10.6 percentage points in Germany, and dropped by 0.6 in USA. 
is the mirror image of the US situation, as German economy would be smaller, and its unemployment larger if it (ceteris paribus) had a balanced trade position. China is currently in between these two positions, with its erstwhile very large surplus $(8.7 \%$ GDP in 2007) reduced to $0.8 \%$ GDP in 2018. However, it remains a winner in international markets and its short-term motivations are clearly different to those found in USA. We should bear this context in mind when approaching the issue of the trade war of recent years.

As we have seen, there are short-term political motivations to recent US protectionism. However, the rise of China and its strategies of "Made in China 2025" (increasing the technological complexity of Chinese manufacturing) and "Belt and Road" (actively developing closer economic ties with much of the rest of the world) may have caused some hegemonic apprehension in USA (Kim, 2019; Kwan, 2020). However, the results of this form of decoupling are not yet entirely visible - even as it can be surmised, they have hurt both parties. Itakura (2020) uses a general equilibrium model to assess the effects of the 2018/19 trade war and estimates the losses to the GDPs of China $(-1.41 \%)$ and USA $(-1.35 \%)$ as similar.

In such a context, the crisis connected with the responses to the COVID-19 pandemic has begun developing. Its final results in terms of growth cannot yet be fully known. Table 2 brings the current IMF estimates for real GDP growth in 2020 and 2021 as well as data for growth achieved in 2019.

Table 2.

Real growth in \% in selected economies for 2019, and current IMF estimates for 2020 and 2021

\begin{tabular}{|l|c|c|c|}
\hline & 2019 growth & $\begin{array}{c}\text { 2020 growth (January } \\
\text { 2021 estimate) }\end{array}$ & $\begin{array}{c}\text { 2021 growth (January } \\
\text { 2021 estimate) }\end{array}$ \\
\hline USA & 2.2 & -3.6 & 5.1 \\
\hline Germany & 0.6 & -5.4 & 3.5 \\
\hline PR China & 6.0 & 2.3 & 8.1 \\
\hline Canada & 1.9 & -5.5 & 3.6 \\
\hline France & 1.5 & -9.0 & 5.5 \\
\hline UK & 1.4 & -10.0 & 4.5 \\
\hline Japan & 0.3 & -5.1 & 3.1 \\
\hline Russia & 1.3 & -3.6 & 3.0 \\
\hline
\end{tabular}

Source: IMF, 2021

China stands out, as its growth in 2019 was very strong by Western standards. Although it represents a continuation of a worrisome trend in slowing growth from the Chinese point of view (the new normal), used as it is to decades of higher rates of growth. Likewise, its growth estimate for 2020 is impressively positive. Other econo- 
mies have had unimpressive growth in 2019 (except USA, whose 2.2\% is high by its historic standards), and the estimated growth rates for this year vary significantly. Overall, IMF's estimates for growth in 2020 have continuously and significantly improved in each new database update. The GDP contraction in USA for 2020 was estimated at $-3.6 \%$ in January 2021, which is a substantial improvement from the estimate of $-8 \%$ made in June 2020. In the same interval, Russia was upgraded to $-3.6 \%$ from $-6.6 \%$ and France to a still disastrous $-9 \%$ from $-12.5 \%$. If the growth estimates for next year should prove correct, 2021 growth will only somewhat alleviate the global economic situation. China stands out once again, as it did not experience a contraction in 2020 at all, but should benefit from stronger growth in 2021 nonetheless.

These contractions are also under the influence of waning trade, the trends of which are also under the influence of an adverse situation of recent years. US merchandise exports experienced a particularly troubling April and May -dropping by $32.7 \%$ in this period (while usual seasonal fluctuations in previous years were in the 4-6\% range), and while there were improvements in future months, the most recent data currently available (for November 2020) still show merchandise exports which are $7.3 \%$ lower than November 2019, and 9.5\% lower than November 2018. US imports seem to be recovering more quickly and this may result in further issues for the trade deficit. The growth of Chinese exports was comparatively unproblematic. In the same March-May 2020 period, they grew by $11.8 \%$ and the most recent data (for December 2020) show an increase of $18.1 \%$ compared with December 2019, and a $27.7 \%$ increase compared with December 2018. Quite opposite from the US case, imports grew at a slower rate and December 2020 shows an increase of $6.5 \%$ compared to December 2019 and an increase of $24.2 \%$ compared to December 2018 (own calculations from WTO, 2021). All of this leaves China in a relatively favorable position. Its increasing resilience on domestic markets in its growth helps it to reduce structural vulnerability to international markets. The nominal value of its exports is increasing nonetheless, and its growth prospects are relatively optimistic.

\section{Instead of Conclusion: COVID-19 scenarios and Global Order(s)}

The analysis of New World Order(s) is often used in methods of prediction in IR. In contrast, geopolitical scenarios do not predict future events following known trends but insist on the analysis of the influence of unpredictable factors, so called Black Swans (Taleb, 2009) or Wild Cards. As Balaman defined "scenario analysis is conducted, to analyse the impacts of possible future events on the system performance by taking into account several alternative outcomes, i.e., scenarios, and to present different options for future development paths resulting in varying outcomes and corresponding implications" (Balaman, 2019: 137). Although coming from the field of engineering Balaman summarizes the essence of this qualitative method that includes 
demographical, geographical, economic, political, and resource data combining it with STEEP (social, technical, economic, environmental, political) trends (Bradfield et. all, 2005). The advantages this method generates are the inclusion of unpredictable factors like alternative futures, changes in values, unprecedented rules or discoveries (Mendonca et. all, 2009). Gausemeier et. all (1998) introduced the term dynamic scenarios. Combining uncertainties and givens (Meinert, 2014) scenario analysis offers alternative worlds in near future due to the analysed phenomenon.

Existing scenarios (Bobbit, 2020; Steil, 2020; Stainberg, 2020; The Economist) analyse the consequences that the pandemic underlined as non-functional in the current world order. For instance Philip Bobbitt (2020) offers a future scenario of a deepening crisis of constitutional order in major nation-states. Brands and Gavin (2020:38) agree since "world orders are, to a great extent, a reflection of the policies and values of the most powerful global actors." They believe that "COVID has revealed significant weaknesses in the post-Cold War order" (Brands and Gavin, 2020: 38). Benn Steil (2020) models for US post-pandemic foreign economic policy include economybased scenarios that influence global economy system. The first one is One World, in which USA and China "can coexist on a mutually beneficial basis within a set of common rules, norms, and institutions governing economic exchange." (385). The second model named Isolationism, stands for a long-lasting doctrine of non-involvement in international "alliances, foreign economic commitments, [or] international agreements" (392). The third presented model Two Worlds calls upon Cold War practice against a new enemy - China - and could lead to "progressive multilateral decoupling - an escalating quarantining of Chinese firms and industries that persist in either illegal activities (such as espionage and theft) or unfair trade practices (like dumping to eliminate competition)" with a simultaneous construction of "a new multilateral trade regime"(399).

James B. Steinberg (2020) created two scenarios: a pessimistic and an optimistic one. $\mathrm{He}$ argues "negative scenario is not hard to envision; it seems that almost every analyst of global politics has described some variation of this outcome. Even assuming that the pandemic does go away - that we are in a world after COVID-19 rather than a world of COVID-19 - this scenario involves dramatic regression along four key axes: 1. The rollback of globalization; 2. Decisive and adverse shifts in the balance of power; 3. The erosion and perhaps collapse of the liberal order; and 4. The decline of democracy and the ascent of illiberalism and populism." (Steinberg, 2020: 594-599). On the other hand, positive scenario includes similar notions but with opposite outcomes: "1. The pandemic leads not to de-globalization but to re-globalization along geopolitical lines; 2. The pandemic does not result in dramatic, adverse shifts in the balance of power; 3. The liberal order holds and is revitalized; and 4. The pandemic proves deadlier for autocrats and populists than for democrats" (Steinberg, 2020: 599-608). The Economist Intelligence Unit published a paper Geopolitics after COVID-19: is the 
pandemic a turning point? explaining their stands on future events related to the coronavirus. It is believed this crisis "will sharpen great power rivalries and hasten the shift in the global balance of power from west to east. ... pandemic will not usher in an entirely new global order, but it will change things in three important ways: 1 . It will bring to the surface developments that had previously gone largely unnoticed, such as the way in which China has already established spheres of influence in parts of the world that receive little attention; 2. It will act as an accelerant of existing geopolitical trends, in particular the growing rivalry between the US and China and the shift in the economic balance of power from West to East; 3 . Finally, it is likely to be a catalyst for changes that are presently difficult to predict, in both the developed and developing world, from the future of the EU to the relationship between many developing countries and China." (The Economist..., September 2020: 1)

Each of summarized scenarios has similar characteristics - they invoke new order but disagree about its reach; they announce shift in power but disagree about its direction; and introduces new models disagreeing about its form. Therefore, instead of a conclusion, authors summon-up a vision of three possible scenarios due to the previously explained geopolitical games and its economic consequences.

\subsection{Already known games: The rich are getting richer, the poor are getting poorer in a Cold War-like competition}

For Brands and Gavin it seems unlikely that COVID will have transformative effects on the current architecture of world order but "when it comes to institutions, the pandemic has undoubtedly revealed deep-seated weaknesses within many prominent international bodies, from the WHO and WTO to the G7. The need for reform has become clear to all; so has the absence of well-developed institutional structures to deal with a variety of emerging challenges." (Brands and Gavin, 2020: 43) Therefore, "COVID may simply spur a period of much-needed institutional reform and evolution rather than a new start." (Brands and Gavin, 2020: 44) Bobbitt (2020: 146) reminds us of something called "Westphalian Fallacy". The constitutional order of states and state system "has not changed since 1648 and is unlikely to do so now."(ibid.)

Ongoing competition for world power between USA and China vigorously reminds of the Cold War framework for actions in international community. And while some authors find that challenging; (e.g., Ferguson (2020: 821) "Cold War II will be the biggest challenge to world order"); we find it a soothing possibility for international relations because it is easy to manage a system you already know. Yes, technical possibilities are changing, subtle hybrid warfare mechanisms emerging, and new battlefields open daily. But, other than uncertainty in balance of competition and cooperation (Brands and Gavin, 2020), Cold War is an old game with known possible outcomes, not to remind it was actually a time of peace, at least on global level (Woods, 1994). 
In this first introduced scenario, Stiel's (2020: 399) notion of "Two Worlds" lives up to its full potential.

\subsection{Shock and Surprise: Black Swans in research and development of the vaccine, hybrid warfare and Global Chaos}

Andre Ishii (2020) got the impression trough media that "the pandemic is halting history's drive towards a tectonic geopolitical convulsion, which was seemingly the trend since the beginning of the roaring 20s of this century" (www.geopoliticalmonitor.com, 6/2/2020). But although it seems big shock ups are possible, they are selectively plausible. The possibilities for tectonic changes in world order depend on unprecedented possibilities for action of non-state actors or states on the margin of current geopolitical order. Nevertheless, rouge states disconnected from world order do not have shared knowledge in $\mathrm{R} \& \mathrm{D}$, capacity of finance for individual vaccine development, in which case it could be found only by surprise. Non-state actors, for example terrorist groups, could possibly interfere with the process of distribution of the vaccine, or induce different shake-ups in cyberspace warfare, both of which are not actions that lead to tectonic changes.

Core changes in world order are possible in the current status quo of the pandemic crisis as well. McTague (2020) predicts worrying consequences of possible second-wave "the prospect of the disease taking hold in a developing G20 country - think India - which could see the virus quickly doubling back to Europe and the U.S.; the uncertain impact of technological advances in fields such as artificial intelligence as they are used to help combat the disease's spread; a recession pulling at the ties between the European Union's poor south and wealthy north." (The Atlantic, www.theatlantic. com, 9/24/2020).

Finally, a predicted scenario of global chaos is expected in case new Cold War ends rapidly in favor of China. McTague (2020) imagines a scenario where on the breach of feeling safe in Western world, COVID "takes hold in the developing world. Exhausted, indebted, and desperate for their own economies to get back up to speed, richer countries are too slow to help. Panic ensues. Migrants mass in southern Europe, which is still struggling to pull itself out of a coronavirus-induced depression. Somewhere, a state defaults on debt held largely by Western financial institutions. In the chaos, an autocrat eyes an opportunity for a land grab. A United States already unwilling to take the lead leaves China to step into the void." (The Atlantic, www. theatlantic.com, 9/24/2020) Such scenario would lead to rapid and tectonic changes in global geopolitical order but only in the change of leading roles of the players. The game itself seems to be the same. 


\subsection{New Global Order: Re-globalization and new subjectivity}

New global order induced by the crisis is the one defined by re-globalization as a bottom-up process, with new subjects other than states, and smart business solutions leading towards prosperity rather than geopolitics. Different "kinds of geopolitical shake-ups, combined with the COVID-19 crisis, possess the potential to radically accelerate the transformation of the geopolitical landscape. Add to this mix some Big Data-premised domestic state programs - think tech-based contact tracing that may find a home in wider social applications - that could also potentially alter the balance of power between the state and its public". (www.geopoliticalmonitor.com, 6/2/2020) Such balancing power is no longer being part of global geopolitical games but locally and business oriented. The pandemic has altered business processes, and according to Robert Mikac (2020: 9) research, "it is visible that the operators used the crisis as the opportunity to change part of their own business processes as well as detect an additional number of identified lessons, which, if converted into lessons learned can enable a higher level of preparedness, readiness and effectiveness in dealing with future crises". Resistance and resilience uploaded in collective awareness and strengthened by business relations and processes indeed leads to new rules and regulations in world order leaving it parched of geopolitical competition on state level.

Nevertheless, Steinberg (2020) suggested three possibilities for forming a new global order after COVID-19. All three models are taking into account states as subjects and foresee world leadership by coalitions of the willing, either in institutional, ad hoc, or geographical way. The institutional basis of cooperation is formed around, as he calls it, "directorate" of "systemically important countries" that can "take on the effort to promote cooperation directly or to spin off new groups and arrangements to tackle particular challenges." (558) The idea for the second approach is ad-hoc grouping around challenges and/or interest. As examples for this solution Steinberg (2020: 560) is naming already existing initiatives such as "Major Economies Forum (for climate change), the Nuclear Suppliers Group (NSG), and the Proliferation Security Initiative (PSI) (for nuclear and missile proliferation)". Membership is such groups "need not be fixed", it "can be more specifically tailored to the countries that 'matter' for a particular problem (which can vary from case to case)" and "can be expanded over time to include others who meet membership criteria or performance commitments." (Steinberg, 2020: 560-561) The third Steinberg's (2020: 562) approach is "to rely on regional organizations" due to the fact "they are smaller and may be somewhat more homogeneous than a universal grouping, agreement may be easier, and they offer similar advantages of being an ongoing organization that can tackle emerging problems." It is not stated, but geographical proximity, belonging and tradition of cooperation play a significant role in such a model.

The emergence of a new global order relies on the continuance of the ongoing processes of geopolitical realm: interconnection of territory, new subjectivity and fragmentation of power. The pandemic crisis highlighted rotten parts of globalization 
calling upon easier and more logical interconnections in the regional sense. It highlighted the co-existence of various subjects but also left no room for their actions. State mechanisms of possible international cooperation (against conflict) distribute power in the international arena. It is left to be considered whether global wellbeing and solidarity might prevail current geopolitical competition around COVID-19 issues due to the humane approach health crisis calling upon.

\section{References}

1. Akkerman, M. (2020). COVID-19 and Border Politics. Border Wars Briefings, Amsterdam: Transnational Institute \& Stop Wapenhandel, July 2020.

2. Balaman, Ş. Y. (2019). Decision-Making for Biomass-Based Production Chains. UK and USA: Elsevier Academic Press.

3. Bhagwati, J. (2003). Free Trade Today. Princeton: Princeton University Press.

4. $\quad$ Bradfield, R.; Wright, G.; Burt, G.; Cairns, G.; Heijden, K. Van Der (2005). The origins and evolution of scenario techniques in long range business planning. Futures, 37 (8): 795-812.

5. Brands, H. and Gavin, F. J. (2020). COVID-19 and World Order. Baltimore: Johns Hopkins University Press., pp 23-62.

6. Brands, H.; Feaver, P. and Inboden, W. (2020). Maybe It Won't Be So Bad: A Modestly Optimistic Take on COVID and World Order, in: Brands, H. and Gavin, F. J. (Eds.). COVID-19 and World Order. Baltimore: Johns Hopkins University Press, pp. 584-619.

7. Bobbitt, P. (2020). Future Scenarios: 'We are all failed states, now', in; Brands, H. and Gavin, F. J. (Eds.). COVID-19 and World Order. Baltimore: Johns Hopkins University Press, pp. 129-160.

8. Corum, J.; Wee, S. and Zimmer, C. (2020). Coronavirus Vaccine Tracker. New York Times, https://www.nytimes.com/interactive/2020/science/coronavirusvaccine-tracker.html, updated 9/18/2020. (Accessed 9/22/2020)

9. Czempiel, E. O. (1999). Regionalisierung und Globalisierung - Herausforderungen der deutschen Außenpolitik, Globale Politik für eine globale Welt - Das Vermächtnis von Willy Brandt. Bonn: Friedrich-Ebert-Stiftung, Akademie der politischen Bildung, pp. 24-31.

10. Dicken, P. (2007). Global shift: Mapping the changing contours of the world economy. London: SAGE.

11. Economy, E. (2020). The United States, China, and the Great Values Game, in: Brands, H. and Gavin, F. J. (Eds.). COVID-19 and World Order. Baltimore: Johns Hopkins University Press., pp. 718-755.

12. Euronews.com (2021). Do we need coronavirus 'vaccine passports' to get Europe moving again? Euronews asks the experts, author Walsh, D. updated: 03/02/2021, https://www.euronews.com/travel/2020/12/11/do-we-need-coronavirus-vaccine-passports-to-get-the-world-moving-again-euronews-asks-the-e. (Accesed 2/18/2021) 
13. Fanzo, J. (2020). No Food Security, No World Order, in: Brands, H. and Gavin, F. J. (Eds.). COVID-19 and World Order. Baltimore: Johns Hopkins University Press., pp. 302-342.

14. Ferguson, N. (2020). From COVID War to Cold War: The New Three-Body Problem, in: Brands, H. and Gavin, F. J. (Eds.). COVID-19 and World Order. Baltimore: Johns Hopkins University Press., pp. 816-854.

15. Freedman, L. (1991). The Gulf War and the New World Order. Survival, 33 (3): 195-209.

16. Furlong, A. (2020). .The ultimate geopolitical game - distributing a coronavirus vaccine. https://www.politico.eu/article/the-ultimate-geopolitical-game-distributing-a-coronavirus-vaccine/. (Published 7/27/2020; Accessed 7/29/2020)

17. Gausemeier, J.; Fink, A. and Schlake, O. (1998). Scenario Management. Technological Forecasting and Social Change, 59 (2): 111-130.

18. Giddens, A. (2009). The politics of climate change. Cambridge: Polity Press.

19. Gruppe von Lissabon (1997). Grenzen des Wettbewerbs. Die Globalisierung der Wirtschaft und die Zukunft der Menschheit. Bonn: Lizenzausgabe für die Bundeszentrale für politische Bildung.

20. Hall, P. and Soskice, D. (Eds.). (2001). Varieties of Capitalism: The Institutional Foundations of Comparative Advantage. Oxford: Oxford University Press.

21. Haro Sly, Maria J. (2020). "SOBERANA-01, a vacina cubana contra o COVID-19", https://www.americalatina.net.br/soberana-01-a-vacina-cubana-contrao-covid-19-maria-haro-sly/?fbclid=IwAR2PT7urhEms23tjlWpZwoOPfKSTSTI 5Zb5h6b707tvtErHRngUpL8gKsFs. (published 9/23/2020; accessed 9/28/2020)

22. Hobbs, J. E. (2020). Food Supply Chains during the COVID-19 Pandemic. Canadian Journal of Agricultural Economics, special issue (April 2020): 1-6.

23. Huntington, S. P. (1998). The Clash of Civilizations and the Remaking of World Order. New York: Simon \& Schuster.

24. Ietto-Gillies, G. (2005). Transnational corporations and international production: concepts, theories and effects. London: Edward Elgar Publishing.

25. IGM Economic Experts Panel (2012). Free Trade. https://www.igmchicago.org/ surveys/free-trade/. (Accessed 9/28/2020)

26. IMF (2021). World Economic Outlook Update, January 2021, available at https://www.imf.org/-/media/Files/Publications/WEO/2021/Update/January/ English/data/WEOJan2021update.ashx. (Accessed 2/23/2021)

27. Inglesby, T. (2020). Make Pandemics Lose Their Power, in: Brands, H. and Gavin, F. J. (Eds.). COVID-19 and World Order. Baltimore: Johns Hopkins University Press., pp. 160-195.

28. Ishii, A. (2020). Geopolitics, History, and the Post-COVID World, Geopolitical Monitor, https://www.geopoliticalmonitor.com/geopolitics-history-and-thepost-covid-world/. (Published 6/2/2020; Accessed 6/10/2020)

29. Itakura, K. (2020). Evaluating the impact of the US-China trade war. Asian Economic Policy Review, 15 (1): 77-93. 
30. Kim, Min-hyung (2019). A real driver of US-China trade conflict: The SinoUS competition for global hegemony and its implications for the future. International Trade, Politics and Development, 3 (1): 30-40.

31. Knock, T. J. (2019). To End All Wars, New Edition: Woodrow Wilson and the Quest for a New World Order. Princeton: Princeton University Press.

32. Kwan, C. H. (2020). The China-US trade war: Deep-rooted causes, shifting focus and uncertain prospects. Asian Economic Policy Review, 15 (1): 55-72.

33. Lara-Valencia, F.; Agulló, J.; García-Pérez, H.; Oliveras, X.; Trillo, J. M. (2020). COVID-19 and cross-border mobility. Tempe, Arizona: Transborder Policy Lab, Arizona State University.

34. Liu, T. and Woo, W. T. (2018). .Understanding the US-China trade war. China Economic Journal, 11 (3): 319-340.

35. Lučev, J. (2021). Systemic Cycle and Institutional Change: Labor Markets in USA, Germany and China. Palgrave Macmillan.

36. Lučev, J. i Babić, Z. (2013). Tipovi kapitalizma, ekspanzija neoliberalizma i socijalni učinci u baltičkim zemljama, Sloveniji i Hrvatskoj: komparativni pristup. Revija za socijalnu politiku, 20 (1): 1-20.

37. McTague, T. (2020). The Pandemic's Geopolitical Aftershocks Are Coming Western capitals aren't just worried about the risk of a resurgence in coronavirus cases. The Atlantic, https://www.theatlantic.com/international/archive/2020/05/ coronavirus-pandemic-second-wave-geopolitics-instability/611668/, published 5/18/2020. (Accessed 9/24/2020)

38. Meinert, S. (2014). Field manual - Scenario building. Brussels: Etui. www.etui. org. (Accessed 4/10/2020)

39. Mendonça, S.; Cunha, M. Pina e; Ruff, F.; Kaivo-oja, J. (2009). Venturing into the Wilderness. Long Range Planning. 42 (1): 23-41.

40. Mikac, R. (2020). Impact of the COVID-19 pandemic and crisis on the operations of critical infrastructure and essential services operators in South East Europe. World Security Report, Autumn 2020. www.worldsecurity-index.com. $(9 / 28 / 2020)$

41. Nye, Jr; Joseph S. (1992). What New World Order. Foreign Affairs, https:// www.foreignaffairs.com/articles/1992-03-01/what-new-world-order. (Published Spring 1992; Accessed 10/10/2020)

42. Ó Tuathail, G. (2000). Borderless Worlds? Problematising Discourses of Deterritorialisation, in: Newman, D and Kliot, N. (Eds.). Geopolitics at the End of the Twentieth Century. The Changing World Political Map. London - Portland: Frank Cass, pp. 139-155.

43. OECD (2020). Trade in goods and services. https://data.oecd.org/trade/trade-ingoods-and-services.htm. (9/28/2020)

44. Ravenhill, J. (2011). The Study of Global Political Economy, in: Ravenhil, J. (Ed.). Global political economy. Oxford: Oxford University Press (1-28). 
45. Rodrik, D. (2020). Globalisation after COVID-19: My Plan for a Rewired Planet. Prospect, May 4, 2020, https://www.prospectmagazine.co.uk/magazine/ dani-rodrik-globalisation-trade-coronavirus-who-imf-world-bank. (Published 5/4/2020; Accessed 10/10/2020)

46. Sassen, S. (Ed.). (2020). Global Networks -Linked Cities. NY: Routledge

47. Schake, K. (2020). Building a More Globalized Order, in: Brands, H. and Gavin, F. J. (Eds.). COVID-19 and World Order. Baltimore: Johns Hopkins University Press., pp. 649-681.

48. Schengen visa info news (2021). List of EU Countries Issuing/Asking for Vaccination Certificates. February 4, 2021, https://www.schengenvisainfo.com/ news/list-of-eu-countries-issuing-asking-for-vaccination-certificates/. (Accesed 2/18/2021)

49. Slaughter, A.-M. (1997). The Real New World Order. Foreign Affairs, https:// www.foreignaffairs.com/articles/1997-09-01/real-new-world-order. (Published September 1997 / October 1997; Accessed 10/10/2020)

50. Steinberg, J. B. (2020). A “Good Enough” World Order: A Gardener's Manual, in: Brands, H. and Gavin, F. J. (Eds.). COVID-19 and World Order. Baltimore: Johns Hopkins University Press. pp. 547-583.

51. State of the Union Address by President von der Leyen (2020). https://ec.europa. eu/commission/presscorner/detail/en/speech 20 1655?fbclid=IwAR2ZTWzbF 20kM6D4egkx-P7f5LqjuEjRKceAh4QV-q24zaomzfHWjbUe1SI. (Published 9/17/2020; Accessed 9/17/2020)

52. Steil, B. (2020). Models for a Post-COVID US Foreign Economic Policy, in: Brands, H. and Gavin, F. J. (Eds.). COVID-19 and World Order. Baltimore: Johns Hopkins University Press., pp. 381-406.

53. Taleb, N. N. (2009). Crni labud: Utjecaj krajnje nevjerojatnog. Zagreb: Jsesenski i Turk.

54. The Economist (2020). Which market model is best?. (September 12th, 2020)

55. The Economist Intelligence Unit (2020). Geopolitics after COVID-19: is the pandemic a turning point? http://country.eiu.com/article.aspx?articleid=1339 299717\&Country $=$ Albania\&topic $=$ Politics\&subtopic $=$ Forecast\&subsubtopic $=$ International+relations. (Published September 2020; Accessed 9/27/2020)

56. WHO (2020a). "Immunity passports" in the context of COVID-19, Scientific Brief. https://www.who.int/news-room/commentaries/detail/immunity-passports-in-the-context-of-covid-19, 4/24/2020. (Accesed 2/18/2021)

57. WHO (2020b). Draft landscape of COVID-19 candidate vaccines. https://www. who.int/publications $/ \mathrm{m} /$ item/draft-landscape-of-covid-19-candidate-vaccines. (Published 9/17/2020; Accessed 9/22/2020)

58. WHO (2021). Draft landscape and tracker of COVID-19 candidate vaccines. https://www.who.int/publications/m/item/draft-landscape-of-covid-19-candidate-vaccines. Published 2/23/2021; Accessed 2/26/2021)

59. Woods, R. B. (1994). Review: Cold War or Cold Peace. The International History Review, 16 (1): 81-91. 
60. WTO (2020). Regional trade agreements. https://www.wto.org/english/tratop_el region_e/region_e.htm. (Accessed 9/28/2020)

61. WTO (2021). Data. https://data.wto.org/. (Accessed 2/23/2021)

62. Zimmer, C.; Corum, J. and Wee, S.-L. (2021). Coronavirus Vaccine Tracker. New York Times, https://www.nytimes.com/interactive/2020/science/coronavirus-vaccine-tracker.html. (Updated 2/25/2021; Accessed 2/26/2021)

63. Zorko, M. (2018). Geopolitika i teritorijalnost. Zagreb: Jesenski i Turk. 


\title{
Geografski uzorci i geoekonomsko promišljanje pandemijskih posljedica: stare geopolitičke "igre" globalnog post-COVID poretka
}

\author{
Marta Zorko \\ Sveučilište u Zagrebu, Fakultet političkih znanosti, Hrvatska \\ e-mail: marta.zorko@fpzg.hr \\ Josip Lučev \\ Sveučilište u Zagrebu, Fakultet političkih znanosti, Hrvatska \\ e-mail: jlucev@gmail.com
}

\section{Sažetak}

Istraživanje donosi dvodimenzionalnu analizu posljedica pandemije COVID-19 na globalni svjetski poredak nakon 2020. godine. Prva dimenzija analize orijentirana je prema geopolitičkim parametrima, dok se druga bazira na geoekonomskim posljedicama pandemijske krize. Autori su identificirali tri tipa geopolitičkih igara u međunarodnoj zajednici: igru zabrane kretanja i etiketiranja; igru utrke oko cjepiva i igru sekuritizacije. Cilj je istražiti njihove potencijalne posljedice po gospodarstvo određenih zemalja, ali i postulate međunarodne političke ekonomije $s$ obzirom na suvremene geografske, političke i ekonomske uzorke ponašanja u pandemiji. Središnja teza usmjerena je prema potvrđivanju predvidljivih i uobičajenih uzoraka ponašanja koje prate isprobani mehanizmi pokušaja ostvarivanja moći u međunarodnoj zajednici (klasične geopolitičke igre moći u novim uvjetima). Glavni cilj ovog rada je izrada scenarija potencijalnih promjena u odnosima moći na globalnoj razini i analiza posljedica s obzirom na ishode triju navedenih igara. Analiza scenarija uobičajena je geopolitička kvalitativna metoda koja se najčešće koristi za procjenu rizika u različitim sferama društva. Najčešće se njome služe velike korporacije pri izračunu financijskih fluktuacija kod poslovnih procesa i pri donošenju odluka, ali se pojavljuje i u čitavom nizu projekcija i kod industrijsko- tehnoloških procesa i pri američkim institutima. Slična je metodologija i u slučajevima financijskih analiza scenarija, dok se u ostalim društevnim znanostima (prvenstveno geopolitici i sigurnosnim studijama) radi o otkrivanju potencijalnih i alternativnih svjetova. U geopolitici služi za projekciju potencijalnih razvoja događaja u globalnom okruženju s obzirom na kreiranje novih svjetskih poredaka, te fenomene koji mogu mijenjati predviđene ishode stvarnosti. Dok se analize novih svjetskih poredaka mogu pripisati i metodama predviđanja u međunarodnim odnosima; za razliku od njih, analize scenarija nisu samo prognoze razvoja događaja utemeljene na prošlim trendovima. One prvenstveno uključuju razmatranja nepredvidljivih faktora odnosno obrata u međunarodnim odnosima, gdje je pandemija svjetskih razmjera zasiguno jedan od njih.

Ključne riječi: geopolitika, geoekonomija, pandemija, COVID-19, globalni svjetski poredak. 